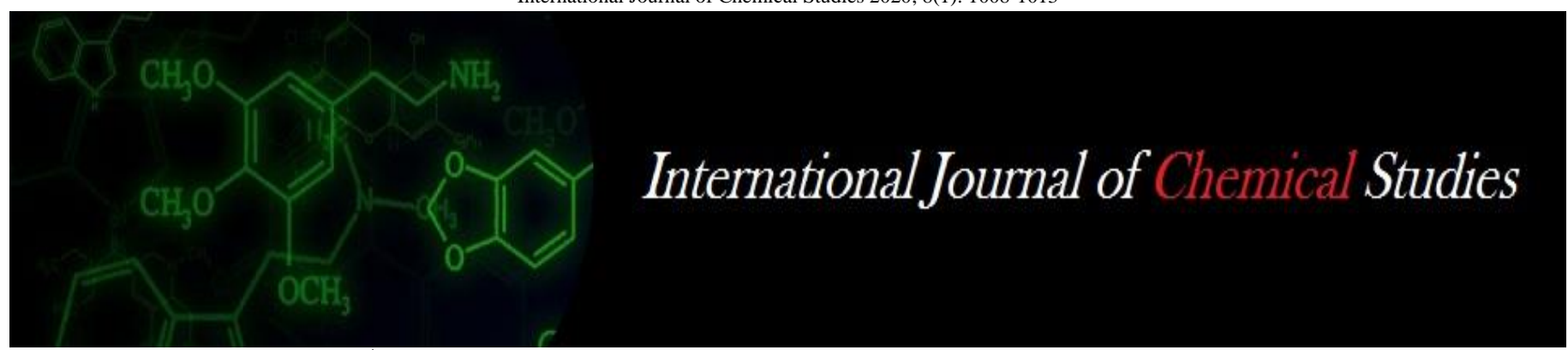

P-ISSN: 2349-8528

E-ISSN: 2321-4902

IJCS 2020; 8(1): 1008-1013

(C) 2020 IJCS

Received: 19-11-2019

Accepted: 23-12-2019

Rakesh Banwasi

Department of Soil Science and Agriculture Chemistry, College of Agriculture, IGKV, Raipur,

Chhattisgarh, India

\section{SK Singh}

Division of Remote Sensing Applications, ICAR-National

Bureau of Soil Survey and Land

Use Planning, Nagpur,

Maharashtra, India

\section{Nirmal Kumar}

Division of Remote Sensing Applications, ICAR-National Bureau of Soil Survey and Land Use Planning, Nagpur,

Maharashtra, India

\section{KK Sahu}

Department of Soil Science and Agriculture Chemistry, College of Agriculture, IGKV, Raipur, Chhattisgarh, India
Corresponding Author: Rakesh Banwasi

Department of Soil Science and Agriculture Chemistry, College of Agriculture, IGKV, Raipur,

Chhattisgarh, India

\section{Characterization and classification of soils of Bemetara under rice and soybean based cropping systems}

\author{
Rakesh Banwasi, SK Singh, Nirmal Kumar and KK Sahu
}

DOI: https://doi.org/10.22271/chemi.2020.v8.i1m.8378

\begin{abstract}
A study was conducted on the soils under rice and soybean based cropping systems in Bemetara block of Bemetara District, Chhattisgarh in order to characterize and classify them. The investigation revealed that the rice growing soils were very deep, dark grayish in color (10 YR 3/2) and clayey in texture throughout the depth, with presence of slickensides in the sub-surface layers. During the summers, the soils exhibited wide spread cracks on the surface, extending to the surface of the slickensides. Periodic opening and closing of cracks, clay content more than $30 \%$ rich in smectites and the presence of slickensides thicker than $25 \mathrm{~cm}$ in these soils qualify them to Vertisols. In absence of slickensides and wedge shaped soil structure in the sub-surface and clay content less than $35 \%$ below the surface, the soybean growing soils could not qualify for Vertisols and placed in the other soil order, Inceptisols.
\end{abstract}

Keywords: Characterization, classification, soybean based, cropping systems

\section{Introduction}

Agriculture is the main occupation of nearly $75 \%$ of the population of the Chhattisgarh. Chhattisgarh is known as rice bowl of India. Chhattisgarh produces 7.98 million tonnes rice from 4.03 mha area with $1978 \mathrm{~kg}$ ha-1productivity. Bemetara district in Chhattisgarh is one of the premier districts known for producing rice and soybean. Rainfed agriculture is common with traditional practice in the district. Productivity of the district for paddy $(17.08 \mathrm{q} / \mathrm{ha})$, soybean $(5.51 \mathrm{q} / \mathrm{ha})$ and wheat crop $(9.92 \mathrm{q} / \mathrm{ha})$ are very low in comparison of the national productivity $23.91,9.51$ and $27.50 \mathrm{q} /$ ha for rice, soybean and wheat crop, respectively (Agricultural Statistics. 2015) ${ }^{[1]}$. Degradation of the land resources is one of the major problems for raising the productivity. Blanket recommendation and uniform land use without considering the potentiality and problem of land resources are the major causes of low productivity and land degradation in the district.

There is urgent need to increase the production and the productivity of rice and soybean to feed the rising population and associated need for increased agricultural production, there is great necessity for improving management and sustainable utilization of the land resources specially the soils and water. Land evaluation is a prerequisite to achieve optimum utilization of available land for agricultural production in a sustainable manner. The detailed spatial information on land resources is essential for land evaluation (Burrough, 1989; Maji et al., 2001, 2002; Reddy et al., 2001, 2015) [5,11,12,16] for following various approaches and methodologies developed (Storie, 1954; Ricquier et al., 1970; FAO, 1976) ${ }^{[6,17] .}$.

For successful execution of land evaluation programme, a comprehensive knowledge of soils with respect to their characteristics, classification, location, extent and distribution, potentials and problems is prerequisite (Thilagam and Sivasamy, 2013). Systematic study of morphology and taxonomy of soils provides information on nature and type of soils, their constraints, potentials, capabilities and their suitability for various uses.

The present investigation aims to evaluate the, soil and site characteristics to determine the degree of suitability for paddy and soybean in Bemetara block in Bemetara district of Chhattisgarh which has $1027 \mathrm{~mm}$ annual average rainfall and comes under the Agro Ecological Region (ICAR)-10 [J6C4(3)] 
and described as hot sub-humid agro-eco region with moderately deep black soils (inclusion of red soils) and LGP 150-180 days. The agro-ecoregion covers eastern plateau of Satpura, Mahanadi basin and fringes of Maharashtra plateau and covers 15.2 mha areas (4.6\% of the TGA) in Chhattisgarh, Madhya Pradesh and Maharashtra (NBSS\&LUP, 1995) ${ }^{[13]}$. The region is the house of 38.39 million people and $17.50 \mathrm{~m}$ livestock (Indian livestock Census, 2012). Farmers of the region are resource poor. The Similar kind of study has been taken elsewhere in the country (Bobade et al., 2010; Sharma et al., 2011; Selvaraj and Naidu, 2013; Saroj et al., 2014; Yadav and Hooda, 2014) ${ }^{[4,18,19] .}$

However, such kind of study is yet to be attempted in this part of the state. Therefore the present investigation was carried out in some part of Bemetara tehsil of Bemetara district, Chhattisgarh to evaluate the soils for paddy and soybean based cropping system.

\section{Methods and Materials \\ Location}

Bemetara block belongs to Bemetara district of Chhattisgarh and is located in the centre of Mahanadi basin. Geographically, it is located between $21^{0} 58^{\prime}$ to $22^{0} 00^{\prime} \mathrm{N}$ latitude and $81^{\circ} 28^{\prime}$ to $81^{\circ} 32^{\prime} \mathrm{E}$, covering an area of 2841.65 ha (Fig 3.1-1) .The study area is part of the Mahanadi Basin which is the $8^{\text {th }}$ largest basin in the country with a catchment area of 139681.51 sq. $\mathrm{km}$ between $80^{\circ} 30^{\prime}$ to $86^{\circ} 50^{\prime} \mathrm{E}$ longitude and $19^{\circ} 21^{\prime}$ to $23^{\circ} 35^{\prime} \mathrm{N}$ latitude covering the states of Chhattisgarh and Odisha and comparatively smaller spread in Jharkhand, Maharashtra and Madhya Pradesh. In the state of Chhattisgarh, Mahanadi basin is associated with Baghelkhand plateau, Chotanagpur plateau, Dandakaranya, which all are the constituents of eastern plateau (Singh et al. 2016). Thus the study area was classified as the part of eastern plateau (E) at the physiographic level. Further the study area was classified as the part of Mahanadi basin at subphysiographic level (Em). It has been taken down as a part of sedimentary deposits $\left(\mathrm{EmS}_{\mathrm{d}}\right)$ at the level of broad landforms. EmSd was further classified into upland and flood plains. The first landform represents the basalt flow and its aggregation, whereas flood plains represent the junction of basalt and purana sedimentary basin of Chhattisgarh. Srivastava et al. (2016) also reported basaltic flow and its aggregation in the part of Chhattisgarh state.

\section{Climate}

The study area comes under the Agro-Climatic Zone -7, Eastern Plateau and Hills Region (Planning Commission) and represents Agro Ecological Region (ICAR) - 10 [J6C4(3)]: Hot sub-humid agro-eco region with moderately deep black soils (inclusion of red soils) and LGP 150-180 days. The climate of the area is tropical, sub-humid with well-expressed summer (April to May), monsoon season (June to September), post-monsoon season (October to December) and winter season (January to March).

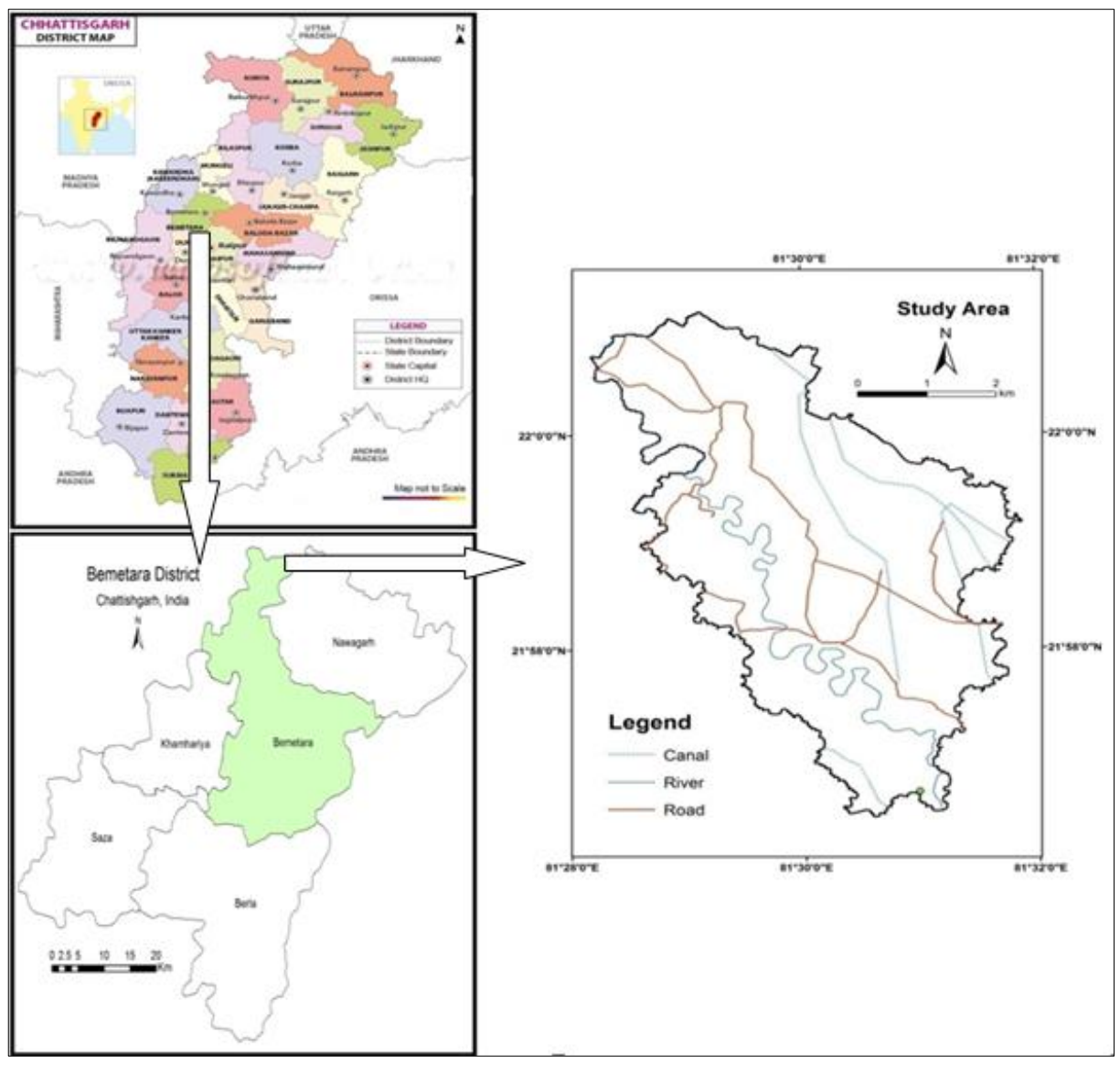

Fig 1: Study area location

The study area receives rainfall mainly from south-west monsoon. It sets in third/fourth week of June and continues till mid-August/September with heaviest showers in the months of July and August and nearly 95\% of the annual rainfall is received during this period. The average annual rainfall for the study area is around $1076.9 \mathrm{~mm}$ (District Survey Report, Bemetara, 2016).Monthly rainfall data (mm) of Bemetara district during 2012 -2016 was given in the table3.1.3. 


\section{Soil survey and soil site characterization}

To understand the soil variability in the study area, representative soil profiles were studied. Based on the interpretation of satellite data, landform, and cropping systems adopted in the area, representative 16 soil profiles were selected for the study. Profiles of size $1.5 \mathrm{~m} \mathrm{x} 1.0 \mathrm{~m}$ with depth of $1.5 \mathrm{~m}$ or up to murum layer were dug and examined for various morphological properties as suggested in the USDA Soil Survey Manual (Soil Survey Staff, 1998) ${ }^{[24]}$. Special observations regarding the depth and width of cracking and also the extent of slickensides were also recorded. Various site and soil characteristics like slope, stoniness, erosion, colour, texture, structure etc. were recorded in standard format. Soils were classified according to Keys to Soil Taxonomy (Soil Survey Staff, 2003) ${ }^{[25]}$.

Nearly $2.0 \mathrm{~kg}$ of representative soil samples from each horizon of all the representative profiles were collected in cloth bags and properly labeled for the laboratory analysis. Some soil clods from the each soil horizon were also collected for the determination of bulk density.

\section{Morphological characterization of soil profiles}

The soil profiles were examined in the field for morphological characteristics of as per the procedure given in IARI Manual (1971) and USDA Soil Survey Manual (Soil Survey Staff, 1998) ${ }^{c}$. Morphological characteristics of each of the horizons like depth, colour, texture, volume of gravel, structure, consistence, calcareousness, roots, pores, etc. were recorded. Additional information about pressure faces/slickenside, depth and width of cracks, coarse fragment content in soil expressed on volume basis (\%) etc. was also noted.

\section{Physical characterization of soil profiles}

The bulk soil samples collected from the soil horizons of the soil profiles were allowed to dry in the air and then prepared for the physical and chemical analysis in the laboratory. A wooden mortar and pestle was used to crush soil aggregates to pass a $2 \mathrm{~mm}$ sieve. Soil material passing through the sieve was placed in labeled boxes. The bulk density was determined by clod coating method (Black et al. 1965) ${ }^{[3]}$. Air dried clods collected from soil profiles were weighed and their bulk volume was determined by water displacement by clod coated with melted paraffin wax. The bulk density $\left(\mathrm{Mg} \mathrm{m}^{-3}\right)$ was expressed on oven dry basis. Particle size distribution was determined as per the international pipette method. Soil was initially treated with $\mathrm{H}_{2} \mathrm{O}_{2}(30 \%)$ for the removal of organic matter and further treated with $\mathrm{HCl}(1 \mathrm{~N})$ to remove $\mathrm{CaCO}_{3}$ using sodium hexametaphosphate as dispersing agent. Sand $(2.0-0.05 \mathrm{~mm})$, silt $(0.05-0.002 \mathrm{~mm})$ and, clay $(<0.002 \mathrm{~mm})$ were separated using the procedure described by Jackson (1967) ${ }^{[8]}$.The textural class was determined using the USDA textural triangle as given in Soil Survey Manual (Soil Survey Division Staff, 2000, Kumar et al. 2018) ${ }^{[11]}$.

\section{Chemical characterization of soil profiles}

Soil $\mathrm{pH}$ was determined in soil suspension (1:2.5 soil: water) by a glass electrode $\mathrm{pH}$ meter after equilibrating soil with water for 30 minutes with occasional stirring as per the method given by Jackson (1958) ${ }^{[7]}$. The supernatant liquid of soil water suspension $(1: 2.5)$ prepared for measuring $\mathrm{pH}$ was also used for measuring electrical conductivity. It was measured by conductivity bridge (Jackson 1973) ${ }^{[9]}$. Organic carbon was determined by wet oxidation (rapid titration) method (Walkley and Black, 1934) ${ }^{[28]}$. Ground soil sample passed through a $0.5 \mathrm{~mm}$ sieve were used for estimating organic carbon. Soil samples were oxidized by potassium dichromate $(1 \mathrm{~N})$ and the conc. $\mathrm{H}_{2} \mathrm{SO}_{4}$ was used to generate the heat of dilution. The amount of dichromate unutilized was determined by back titration with standard ferrous ammonium sulphate solution $(0.5 \mathrm{~N})$. The calcium carbonate was determined by rapid titration method (Piper 1966). The soil was treated with a known volume of $0.5 \mathrm{~N} \mathrm{HCl}$ to neutralize all the carbonates and the unutilized (excess) $\mathrm{HCl}$ acid was back titrated with standard $\mathrm{NaOH}$ solution of $0.25 \mathrm{~N}$ using phenolphthalein as an indicator. CEC $\left(\mathrm{cmol}(\mathrm{p}+) \mathrm{kg}^{-1}\right)$ of soil was determined by saturating the soil with $1 \mathrm{~N}$ sodium acetate ( $\mathrm{pH} 8.2$ for calcareous soil and $\mathrm{pH} 7.0$ for non- calcareous soil). Excess sodium acetate was removed by washing with 95\% methanol till supernatant has an EC of 40- 55 umhos/cm. The adsorbed sodium ions was then replaced and extracted by washing with $1 \mathrm{~N}$ ammonium acetate $(\mathrm{pH} 7.0)$ solution and the leachate was made upto known volume. $\mathrm{Na}^{+}$present in the leachate was determined with a flame photometer and CEC was calculated (Jackson 1967) ${ }^{[8]}$. Exchangeable calcium and magnesium were determined by using $1 \mathrm{NKCl}$ Triethanolamine buffer solution ( $\mathrm{pH}$ 8.2) and titrating the leachate with standard EDTA solution using murroxide and EBT as an indicator (Jackson 1967) ${ }^{[8]}$. Exchangeable sodium and potassium were determined by leaching the soil with $1 \mathrm{~N}$ ammonium acetate $\left(\mathrm{pH}\right.$ 7) solution. $\mathrm{Na}^{+}$and $\mathrm{K}^{+}$from the leachate were estimated by using flame emission spectrophotometer (Jackson, 1967) ${ }^{[8]}$. Base saturation was calculated (Black et al, 1965) [3] as sum of exchangeable cations- $\mathrm{Ca}^{++} \mathrm{Mg}^{++}, \mathrm{Na}^{+}$, and $\mathrm{K}^{+}\left(\mathrm{cmol}(\mathrm{p}+) \mathrm{kg}^{-1}\right)$ divided by CEC $\left(\mathrm{cmol}(\mathrm{p}+) \mathrm{kg}^{-1}\right)$ and multiplied by 100 .

\section{Results and Discussion}

The present study was carried out on soils used for paddy and soybean- based cropping system with the objectives to characterize and evaluate the soils. A total of 16 soil profiles were studied based on the landforms. The profile locations are depicted in the figure 2. After systematic study (Soil Survey Division Staff 2000) of soils' range of characteristics typifying pedons were studied and classified (Soil Survey Staff, 2014). Soil series was tentatively established. Here in the text soils are described cropping system form wise for easy and lucid presentation.

\section{Morphological and physical properties}

All the pedons were deep to very deep with mean thickness of surface horizon varied from $14 \mathrm{~cm}$ to $18 \mathrm{~cm}$. out of 16 soil profiles studied, 13 exhibited dark grayish colour (10 YR3/2) throughout the soil profile and resemble to the color pattern known for deep black cracking soils derived from basalt and basaltic alluvium due to the chelation effect of organic matter on the surface of smectite type of clay minerals (Kumar et al., 2019). Soil texture was clayey throughout the soil profile. It moves the texture known from deep cracking black soils of India and elsewhere. Well developed slickensides tilting an angle of 20 to $60^{\circ} \mathrm{C}$ were prominently seen. The slickensides were breaking to medium moderate to strong angular blocky soil structure. Consistency was friable (moist), very sticky and very plastic (wet) at the surface and firm (moist) very sticky and very plastic (wet) in the sub surface. During the summers, the soils exhibited wide spread cracks on the surface, extending to the surface of the slickensides. Sometimes, cracks used to bisect slickensides vertically.

Three soils studied in the flood plains were similar in properties to the other soils in the surface horizons. However, the colour was slightly different and was registered with 
chroma and value of 4 in 10 YR in the subsurface. The texture of soils of flood plain in subsurface was noted silty clay with clayey texture on the surface. No slickensides were observed in these soils, and structure was moderate sub-angular blocky. Stickiness and plasticity in the sub-surface horizon was comparatively of lower order than that of other soils. The cracking pattern was not that much profuse in these soils. Typifying pedons of the two kinds of soils are seen in figs 2 .

\section{Chemical properties}

All the soils were found neutral in reaction. The organic carbon in the soils was medium to high with a decreasing trend with depth. Calcium carbonate was uniformly distributed in all the soils. Mean content varied from 5 to $6 \%$. Calcium was the dominant cation in the exchange complex with slightly lower content in the three soils of flood plains. Magnesium was the next dominant cation following similar trend as in case of calcium. Sodium cations were very low. However, it was towards slightly higher side in case of the three soils of the flood plain. For the 13 high clay soils, the cation exchange was 42 to $49 \mathrm{C} \mathrm{mol}(\mathrm{p}+) \mathrm{kg}^{-1}$ and increased down the depth with the corresponding figure of 54 to $57 \mathrm{C}$ mol $(\mathrm{p}+) \mathrm{kg}^{-1}$ in the sub-surface. For the other three soils the mean cation exchange capacity was 38 and $40 \mathrm{C} \mathrm{mol}(\mathrm{p}+) \mathrm{kg}^{-1}$ in the surface and just below the surface, respectively. The lowest value of cation exchange capacity was noted 27 to 21 in the lower part of the soil profile.

\section{Soil correlations}

A sequence of Ap, Bw and Bss horizons in the first 13 soil profiles with deep to very deep soil depth class, dark grayish uniform soil colour throughout the profile, clayey texture both at the surface and in the sub-surface and the presence of slickensides and wedge shaped soil structure breaking medium moderate angular blocky (Fig. 3) represent a group of soils. The other three soils at the flood plains with dark grayish colour for first $50 \mathrm{~cm}$ soils with slight variation in chroma and value of 4 than the soils of alluvial plains indicated other group of soils. The variations were also noted in sub-soil texture which was sandy clay loam to silty clay loam. The sequence of the genetic horizon was Ap-Bw-2Bw.

\section{Soil classification}

Periodic opening and closing of cracks, clay content more than $30 \%$ rich in smectites and the presence of slickensides thicker than $25 \mathrm{~cm}$ in the soils of first group which resembled to Vertisols soil order as described in soil taxonomy (Soil Survey Staff, 2014). In absence of slickensides and wedge shaped soil structure in the sub-surface and clay content less than $35 \%$ below the surface, the other group could not qualify for Vertisols and placed in the other soil order, Inceptisols. At the sub-order level based soil moisture regime soil of first and second group were classified into Ustert and Ustepts suborder. Since these two soils did not have any other diagnostic characteristics, therefore soils of both groups were classified into Haplusterts and Haplustepts great groups in Vertisols and Inceptisols soil orders. Since Haplusterts present the central concept of Vertisol soil order therefore these were classified into Typic Haplusterts at sub-group level. The fluvial nature of soils of second group overshadowed the central concept of Inceptisols accordingly these were classified into Fluventic Haplustepts at subgroup of Inceptisol soil order at the subgroup level. At the family level, particle size class, mineralogy and soil temperature regime, the soils of vertisols series were classified into Fine, smectitic (cal.) hyperthermic family of Typic Haplusterts, whereas soils of inceptisols were classified into Fine over fine loamy, mixed hyperthemic family of Fluventic Haplustepts sub-group of Inceptsol soil order. The morphological, chemical, and physical properties of the typifying pedons of these two classes of soils are given in the table 1 and 2.

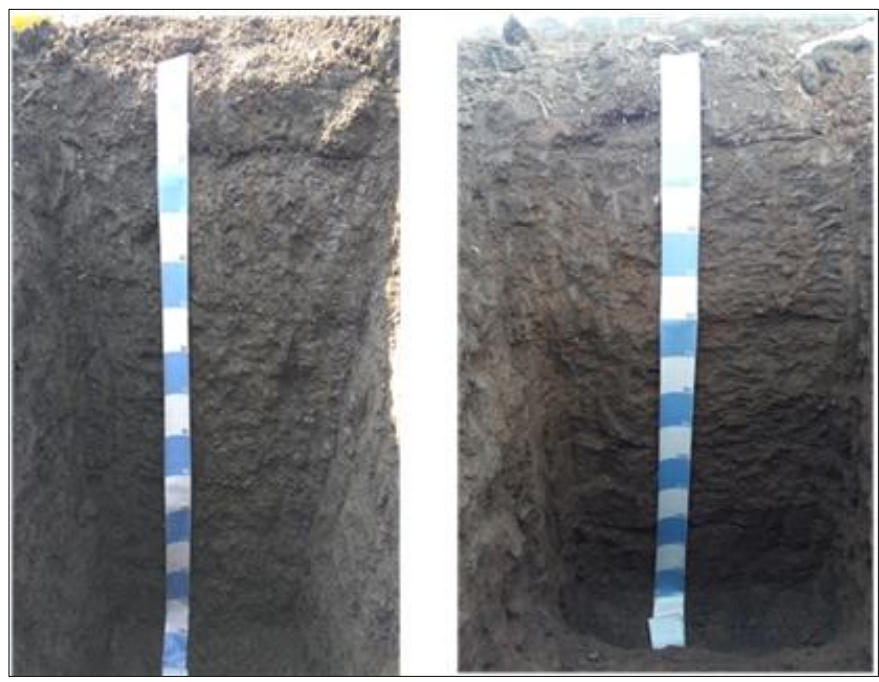

Fig 2: Soil profile pictures of the two typifying pedons, vertisol (left) and inceptisol (left)

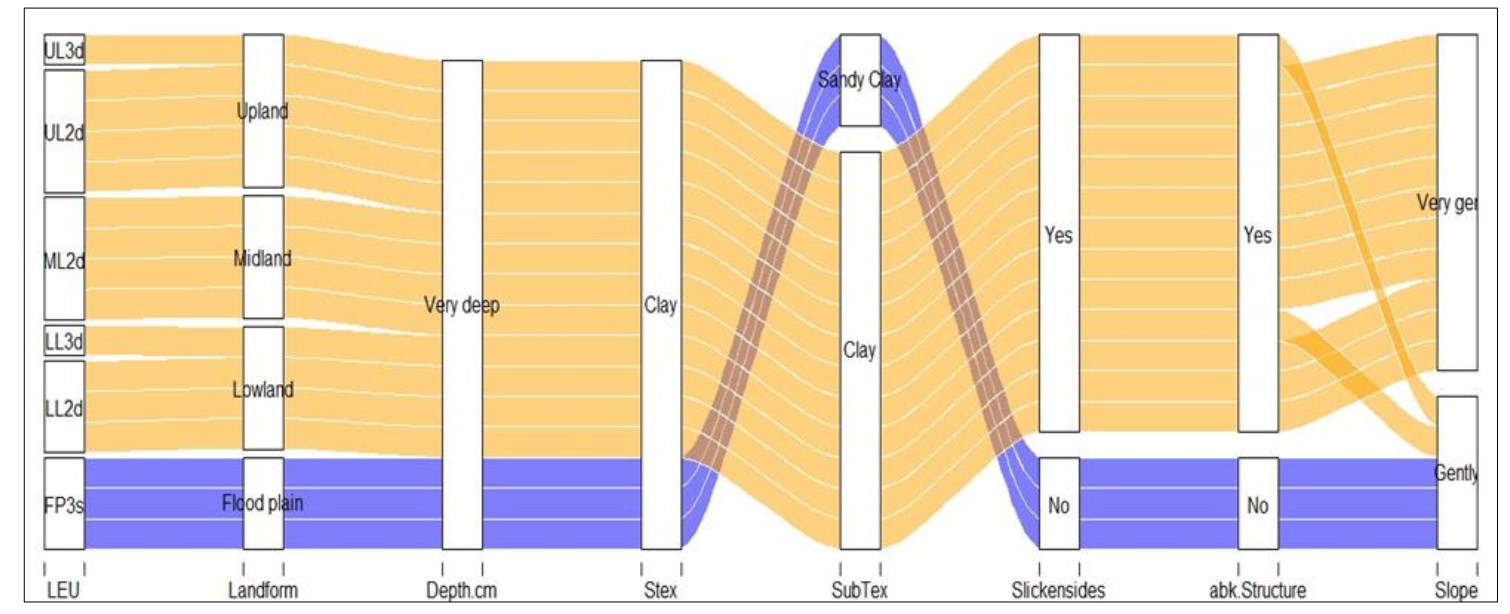

Fig 3: Alluvial diagram showing variations in important soil characteristics 
Table 1: The morphological, physical and chemical characteristics of a typifying pedon of vertisol.

\begin{tabular}{|c|c|c|c|c|c|c|c|c|c|c|c|c|c|}
\hline \multicolumn{14}{|c|}{ Pedon-04: Fine, Smectitic, Hyperthermic, Typic Haplusterts (Gently sloping Upland, Double crop) } \\
\hline \multicolumn{14}{|c|}{$\begin{array}{c}\text { Morphological characteristics } \\
\end{array}$} \\
\hline $\begin{array}{c}\text { Horizo } \\
\mathbf{n}\end{array}$ & $\begin{array}{l}\text { Depth } \\
\text { (cm) }\end{array}$ & $\begin{array}{c}\text { Bounda } \\
\text { ry } \\
\text { D T }\end{array}$ & \multicolumn{2}{|c|}{$\begin{array}{l}\text { Matrix colour } \\
\text { (m) }\end{array}$} & Texture & \begin{tabular}{r|r} 
& $\mathrm{Co}$ \\
fragl & $\mathrm{S}$ \\
$\mathrm{S}$
\end{tabular} & $\begin{array}{l}\text { rse } \\
\text { ients } \\
\%\end{array}$ & $\begin{array}{c}\text { Structure } \\
\text { S G TY }\end{array}$ & $\begin{array}{c}\text { Consistence } \\
\text { D M W }\end{array}$ & $\begin{array}{c}\text { Nodule } \\
\text { Conca } \\
\text { S Q }\end{array}$ & $\begin{array}{c}\text { Roots } \\
\text { S Q }\end{array}$ & $\begin{array}{c}\text { Efferve- } \\
\text { sence }\end{array}$ & $\begin{array}{c}\text { Other } \\
\text { features- }\end{array}$ \\
\hline AP & $0-14$ & $\mathrm{cs}$ & \multicolumn{2}{|c|}{$\mathrm{m} 10 \mathrm{YR} 3 / 2$} & Clay & & \multicolumn{2}{|r|}{$\mathrm{m} 2 \mathrm{sbk}$} & vh - vs vp & $\mathrm{mc}$ & F m & e & - \\
\hline Bw1 & $14-28$ & $\mathrm{cs}$ & \multicolumn{2}{|c|}{ m 10YR 3/2 } & Clay & & \multicolumn{2}{|r|}{$\mathrm{m} 2 \mathrm{sbk}$} & - fr vs vp & $\mathrm{m} \mathrm{m}$ & $\mathrm{Ff}$ & $\mathrm{e}$ & - \\
\hline Bss 1 & $28-40$ & $\mathrm{cs}$ & \multicolumn{2}{|c|}{ m 10YR 3/2 } & Clay & & \multicolumn{2}{|r|}{$\mathrm{m} 2 \mathrm{abk}$} & - fr vsvp & $\mathrm{m} \mathrm{m}$ & F-c f & es & ss \\
\hline Bss2 & $40-59$ & $\mathrm{cs}$ & \multicolumn{2}{|c|}{$\mathrm{m} 10 \mathrm{YR} 3 / 3$} & Clay & & \multicolumn{2}{|r|}{$\mathrm{m} 2 \mathrm{abk}$} & - fr vs vp & $\mathrm{fm} \mathrm{f}$ & F-c vf & es & ss \\
\hline Bss3 & $59-109$ & $\mathrm{cs}$ & \multicolumn{2}{|c|}{ m 10YR 3/3 } & Clay & & \multicolumn{2}{|r|}{$\mathrm{m} 2 \mathrm{abk}$} & - fr vs vp & $\mathrm{fm} \mathrm{f}$ & $\mathrm{c} v f$ & ev & ss \\
\hline Bss4 & $109-150+$ & $\mathrm{g} \mathrm{s}$ & \multicolumn{2}{|c|}{$\mathrm{m} 10 \mathrm{YR} 3 / 3$} & Clay & & \multicolumn{2}{|r|}{$\mathrm{m} 2 \mathrm{abk}$} & - fr vs vp & $\mathrm{fm} \mathrm{f}$ & $\mathrm{c} v f$ & ev & ss \\
\hline \multicolumn{14}{|c|}{ Physical characteristics } \\
\hline \multirow{2}{*}{$\begin{array}{c}\text { Horizo } \\
\mathrm{n}\end{array}$} & \multirow{2}{*}{$\begin{array}{l}\text { Depth } \\
\text { (cm.) }\end{array}$} & \multicolumn{5}{|c|}{ Texture } & \multicolumn{6}{|c|}{ Water retention \% } & \multirow{2}{*}{$\begin{array}{c}\text { BD } \\
\text { gm/cm3 }\end{array}$} \\
\hline & & & ind \% & & Silt \% & Clay \% & & Moisture a & 1/3 bar & $\begin{array}{c}\text { Moisture \% } \\
\text { at } 15 \text { bar }\end{array}$ & & $\%$ & \\
\hline AP & $0-14$ & & 0.40 & & 26.80 & 42.80 & & 33.2 & & 15.48 & & & 1.60 \\
\hline Bw1 & $14-28$ & & 5.80 & & 25.40 & 48.80 & & 30.2 & & 14.61 & & & 1.59 \\
\hline Bss1 & $28-40$ & & 3.60 & & 26.20 & 50.20 & & 30.6 & & 15.94 & & & 1.60 \\
\hline Bss2 & $40-59$ & & 1.00 & & 25.40 & 53.60 & & 30.3 & & 15.00 & & & 1.64 \\
\hline Bss3 & $59-109$ & & 7.00 & & 27.80 & 55.20 & & & & & & & 1.65 \\
\hline Bss4 & $150-109$ & & 4.80 & & 28.60 & 56.60 & & & & & & & 1.64 \\
\hline & & & & & & & Che & emical charac & ristics & & & & \\
\hline Horizo & Depth & pH & EC & OC & $\mathrm{CaCO3}$ & Exch & angea & $\begin{array}{l}\text { ble Cations } \\
\text { soil) }\end{array}$ & (me/100 gm & Sum of & CEC cmoles & $\%$ Base & ESP \% \\
\hline & & & & & & $\mathbf{N a}$ & $\mathbf{K}$ & $\mathbf{C a}$ & Mg & & & & \\
\hline $\mathrm{AP}$ & $0-14$ & 7.72 & 0.25 & 0.71 & 4.88 & 0.33 & 0.38 & 27.50 & 10.30 & 38.51 & 40.58 & 95.52 & 0.86 \\
\hline Bw1 & $14-28$ & 8.07 & 0.22 & 0.52 & 5.58 & 0.28 & 0.32 & 28.10 & 9.90 & 38.60 & 44.78 & 87.14 & 0.73 \\
\hline Bss1 & $28-40$ & 8.22 & 0.15 & 0.49 & 5.75 & 0.26 & 0.34 & 29.40 & 8.90 & 38.90 & 45.38 & 86.65 & 0.67 \\
\hline Bss2 & $40-59$ & 8.29 & 0.2 & 0.43 & 5.83 & 0.2 & 0.3 & 28.60 & 11.40 & 40.50 & 50.98 & 80.35 & 0.49 \\
\hline Bss3 & $59-109$ & 7.72 & 0.17 & 0.34 & 6.53 & 0.22 & 0.32 & 29.90 & 11.80 & 42.24 & 51.58 & 82.47 & 0.52 \\
\hline Bss4 & $150-109$ & 8.17 & 0.19 & 0.27 & 6.85 & 0.22 & 0.34 & 27.50 & 12.70 & 40.76 & 52.18 & 78.61 & 0.54 \\
\hline
\end{tabular}

Table 2: The morphological, physical and chemical characteristics of a typifying pedon of inceptisol.

\begin{tabular}{|c|c|c|c|c|c|c|c|c|c|c|c|c|c|c|c|}
\hline \multicolumn{16}{|c|}{ Pedon-15: Fine mixed, Smectitic, Hyperthermic, Typic Haplustepts (Gently sloping Flood Plain, Double crop) CS } \\
\hline & & & & & & & Morphologic & al charact & ristics & & & & & & \\
\hline $\begin{array}{c}\text { Horizo } \\
n\end{array}$ & $\begin{array}{l}\text { Depth } \\
(\mathbf{c m})\end{array}$ & \begin{tabular}{|c|} 
Bound \\
ary \\
D T
\end{tabular} & \multicolumn{3}{|c|}{$\begin{array}{l}\text { Matrix colour } \\
(\mathbf{m} / \mathbf{r})\end{array}$} & Texture & $\begin{array}{c}\text { Coarse } \\
\text { fragments } \\
\text { SV\% }\end{array}$ & $\begin{array}{l}\text { Struture } \\
\text { S G TY }\end{array}$ & \multicolumn{2}{|c|}{$\begin{array}{c}\text { Consistence } \\
\text { D M W }\end{array}$} & \multicolumn{2}{|c|}{$\begin{array}{c}\text { Nodule } \\
\text { Conca } \\
\text { S Q }\end{array}$} & $\begin{array}{c}\text { Roots } \\
\text { S Q }\end{array}$ & Effervescence & $\begin{array}{c}\text { Other } \\
\text { features }\end{array}$ \\
\hline AP & $0-17$ & $\mathrm{c} \mathrm{s}$ & \multicolumn{3}{|c|}{ m 10YR 3/2 } & Clay & fg $1-3 \%$ & m $1 \mathrm{sbk}$ & \multicolumn{2}{|c|}{- fr s p } & & $\mathrm{f}-\mathrm{m} \mathrm{f}$ & $\mathrm{f} \mathrm{m}$ & es & - \\
\hline Bw1 & $17-57$ & $\mathrm{cs}$ & \multicolumn{3}{|c|}{ m 10YR 3/2 } & Clay & - & $\mathrm{m} 2 \mathrm{sbk}$ & \multicolumn{2}{|c|}{- frsp } & & $\mathrm{f}-\mathrm{c} \mathrm{f}$ & $\mathrm{fff}$ & es & - \\
\hline Bw2 & $57-92$ & $\mathrm{cs}$ & \multicolumn{3}{|c|}{ r 10YR 4/4 } & Clay loam & - & $\mathrm{m} 1 \mathrm{sbk}$ & \multicolumn{2}{|c|}{- fr vs p } & & $\mathrm{ff}$ & $\mathrm{ff}$ & - & - \\
\hline Bw3 & $92-120$ & c s & \multicolumn{3}{|c|}{ r 10YR 4/4 } & $\mathrm{Sc}$ & - & $\mathrm{m} 1 \mathrm{sbk}$ & \multicolumn{2}{|c|}{ - frs p } & & -- & $\mathrm{v}-\mathrm{ff}$ & - & - \\
\hline $\mathrm{Bw} 4$ & $120-150+$ & $\mathrm{cs}$ & \multicolumn{3}{|c|}{ r 10YR 4/4 } & Sc & - & $\mathrm{m} 1 \mathrm{sbk}$ & \multicolumn{2}{|c|}{- fr ss ps } & & -- & $\mathrm{v}-\mathrm{ff}$ & - & - \\
\hline \multicolumn{16}{|c|}{ Physical characteristics } \\
\hline \multirow[b]{2}{*}{$\begin{array}{c}\text { Horizo } \\
\mathbf{n}\end{array}$} & \multirow{2}{*}{$\begin{array}{l}\text { Depth } \\
\text { (cm.) }\end{array}$} & \multicolumn{6}{|c|}{ Texture } & \multicolumn{7}{|c|}{ Water retention \% } & \multirow{2}{*}{$\begin{array}{c}\text { BD } \\
\text { gm/cm3 }\end{array}$} \\
\hline & & \multicolumn{3}{|c|}{ Sand \% } & \begin{tabular}{|c|} 
Silt \\
$\%$
\end{tabular} & \multicolumn{2}{|c|}{ Clay \% } & $\begin{array}{r}\text { Moistur } \\
\text { 1/3 ba }\end{array}$ & & Moistu & e \% & at 15 bar & & AWC \% & \\
\hline AP & $0-17$ & & 22.20 & & 35.80 & & & 25.34 & & & 14.3 & & & 10.95 & 1.58 \\
\hline $\mathrm{Bw} 1$ & $17-57$ & & 21.00 & & 34.40 & & 60 & 24.59 & & & 13.5 & & & 10.99 & 1.64 \\
\hline Bw2 & $57-92$ & & 19.20 & & 35.60 & & 20 & 22.78 & & & 12.5 & & & 10.27 & 1.65 \\
\hline Bw3 & $92-120$ & & 40.80 & & 38.80 & & 40 & 16.95 & & & 8.87 & & & 8.08 & 1.64 \\
\hline $\mathrm{Bw} 4$ & $120-150$ & & 38.00 & & 40.40 & & 60 & & & & & & & & 1.66 \\
\hline & & & & & & & Chemical & haracteris & tics & & & & & & \\
\hline Horizo & Depth & $n$ & EC & OC & $\mathbf{C a C}$ & Exchange & ble Cations & $\mathrm{me} / 100 \mathrm{gl}$ & ( soil) & Sun & & CEC cm & oles $\mathbf{P}^{+} /$ & $\%$ Base & FSD \% \\
\hline $\mathbf{n}$ & (cm.) & pn & $\mathrm{mS} / \mathrm{cm}$ & $\%$ & $\mathrm{O}_{3} \%$ & $\mathrm{Na}$ & $\mathbf{K}$ & $\mathbf{C a}$ & Mg & cati & & & & Saturation & LST \\
\hline AP & $0-17$ & 7.55 & 0.31 & 0.68 & 4.98 & 0.2 & 0.32 & 22.40 & 10.00 & 33 & & 39. & & 82.76 & 0.59 \\
\hline Bw1 & $17-57$ & 7.61 & 0.12 & 0.43 & 5.05 & 0.14 & 0.26 & 23.10 & 9.00 & 32. & & 40. & & 80.49 & 0.43 \\
\hline Bw2 & $57-92$ & 7.66 & 0.16 & 0.25 & 5.12 & 0.18 & 0.24 & 18.90 & 8.90 & 33. & & 31. & & 88.24 & 0.54 \\
\hline Bw3 & $92-120$ & 7.72 & 0.14 & 0.21 & 5.36 & 0.14 & 0.2 & 12.80 & 5.10 & 34. & & 19. & & 93.16 & 0.41 \\
\hline Bw4 & $120-150$ & 7.64 & 0.1 & 0.13 & 5.51 & 0.16 & 0.2 & 13.20 & 5.50 & 35 . & & 20. & 18 & 94.45 & 0.46 \\
\hline
\end{tabular}

\section{References}

1. Agricultural Statistics at a Glance. Directorate of Economics and Statistics, Govt. of India, 2015. www.agricoop.nic.in

http://eands.dacnet.nic.in/PDF/Glance-2015.pdf

2. BIBLIOGRAPHY

3. Black CA. Method of soil analysis part 1. American Soc. Agron. Inc. Agron. 9 Madison USA, 1965, 770.
4. Bobade SV, Bhaskar BP, Gaikwad MS, Raja P, Gaikwad SS, Anantwasr G et al. A GIS-based land use suitability assessment in Seoni district, Madhya Pradesh, India. Tropical Ecology, 2010; 51(1):41-54.

5. Burrough PA. Fuzzy mathematical methods for soil survey and land evaluation. J Soil Sci. 1989; 40:477-492.

6. FAO. Guidelines- land evaluation irrigated agriculture, FAO- Soils Bull. No. 55, FAO, Rome, 1976, 231. 
7. Jackson ML. Soil Chemical Analysis. Prentice Hall, Englewood Cliffs, New Jersey. 1958, 498.

8. Jackson ML. Soil Chemical Analysis. Advance course- II Edition. University of Winsconsin, Madison, USA, 1967, 895.

9. Jackson ML. Soil Chemical Analysis, Prentice Hall India Limited, New Delhi, 1973.

10. Kumar Nirmal, Singh SK, Mishra VN, Reddy GP Obi, Bajpai RK. Open-Source Satellite Data and GIS for Land Resource Mapping. In Geospatial Technologies in Land Resources Mapping, Monitoring and Management, Geotechnologies and the Environment by G. P. O. Reddy, S. K. Singh (eds.), Springer International Publishing AG, 2018, 185-200

11. Maji AK, Nayak DC, Krishna NDR, Srinivas CV, Kamble K, Reddy GPO et al. Soil Information System of Arunachal Pradesh in a GIS Environment for Land Use Planning, Int. J Appl. Earth Obser and Geoinform. 2001; 3:69-77.

12. Maji AK, Srinivas CV, Dubey PN, Reddy GPO, Kamble $\mathrm{KH}$, Velayutham $\mathrm{M}$ et al. Soil Resources Information of Nagaland in GIS for land use planning in Mountainous Region, GIS India. 2002; 11:13-16.

13. NBSS \& LUP. Proceedings of National Meet on Soil-site suitability criteria for different crops, Feb. 7-8, Nagpur, India, 1995, 30.

14. Piper CS. Soil and Plant Analysis, Hans Publishers, Bombay, India, 1966.

15. Reddy GPO, Sarkar D, Mandal C, Srivastava R, Bhattacharyya T, Naidu LGK. Digital Soil Resource Database and Information System In: Geospatial Technology for Integrated Natural Resources Management (Eds. P.S. Roy and R.S. Dwivedi), Yes Dee Publishing Pvt Ltd, Chennai, 2015, 370-406.

16. Reddy GPO. Maji AK, Srinivas CV, Thayalan S, Velayutham M. Landscape Ecological Planning in a Basaltic Terrain, Central India, Using Remote sensing and GIS Techniques, J Indian Soc. Rem. Sen. 2001; 29:3 $-16$.

17. Requier J, Bramap DL, Cornet JP. A new system of soil appraisal in terms of actual potential productivity, Soil Resources Development and Conservation Service, Land and Water Development Division, AGLTESR/7017, FAO, Rome, 1970, 38.

18. Saroj, Sharma, MP, Prawasi, R. Geospatial approach cropping system analysis -A case study of Hisar district in Hariyana. Int. J. Computer Technology \& Applications (IJCTA). 2014; 5(2):457-461.

19. Selvaraj, Naidu MVS. Land characterization and soil-site suitability for the major crops for Reniguntamandal in Chittoor district, Andhra Pradesh. Ind. J. Soil Cons. 2013; 41(1):41-46.

20. Sharma JP, Roychaudhary C. Soil-landform relationship in a basaltic terrain. J Indian Soc. Soil Sci. 1988; 36(4):755-760.

21. Soil Survey Staff. Soil Taxonomy: A Basic System of Soil Classification for Making and Interpretating Soil Surveys. Agriculture Handbook, Vol. 436, SCS, USDA, Washington, DC, 1975.

22. Soil Survey Staff. Keys to Soil Taxonomy, $6^{\text {th }}$ ed. Soil Conservation Service, USDA, Washington, D.C, 1994, 306.

23. Soil Survey Staff. Soil Survey Manual (India print), Handbook No. 18, USDA: Washington D.C, 1995.
24. Soil Survey Staff. Soil Taxonomy: A basic system of soil classification for making and interpreting soil survey. USDA Handbook 436, US Government Printing Office, Washington D.C, 1998.

25. Soil Survey Staff. Key to Soil Taxonomy, Ninth Edition, United State Department of Agriculture, Washington D.C. USA, 2003.

26. Uttam Kumar, Mishra VN, Nirma Kumar, Jena RK, Srivastava LK, Bajpai RK et al. Characterization and classification of soils under rice-based cropping systems in Balod district of Chhattisgarh. Journal of the Indian Society of Soil Science. 2019; 67:228-235.

27. Uttam Kumar, Mishra VN, Nirmal Kumar, Rathiya GR. Methods of Soil analysis. Kalyani Publishers, Ludhiyana, 2018.

28. Walkey AJ Black AI. Estimation of organic carbon by chromic acid titration method. Soil Science. 1934; 25:259-260. 